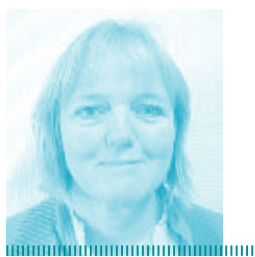

Solveig Tørstad, forsker, Vestre Viken HF

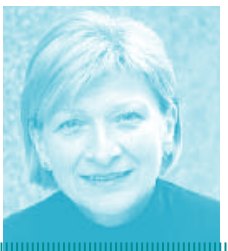

Liv Halvorsrud, førsteamanuensis, Høgskolen iOslo og Akershus

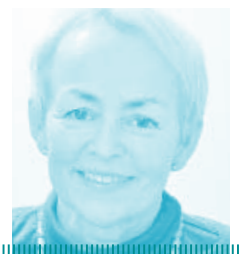

Berit Skjerve, prosjektleder, Bærum kommune

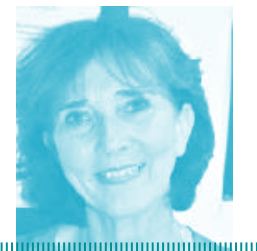

Kari Kongshavn, faglig rådgiver, Bærum kommune

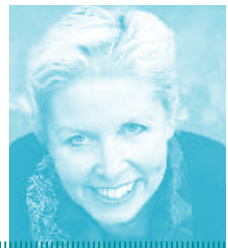

FAG

\section{Praksisstudie}

Margrete Thorstad,

studiesjef, Høyskolen

Diakonova

\title{
Samhandling i praksis
}

\section{Praksismodellen gir studentene innsikt i samarbeid om pasientbehandling på ulike nivåer i helsetjenesten.}

H øyskolen Diakonova, Bærum sykehus og Utviklingssenter for hjemmetjenester i Akershus har sammen utviklet «Samhandlingspraksis». Dette er en praksismodell hvor tredje års sykepleiestudenter har praksis vekselvis i kommune- og spesialisthelsetjenesten, enten innenfor rehabilitering eller kreftbehandling og palliativ omsorg. Praksismodellen er utviklet i tråd med samhandlingsreformen (1) og Stortingsmelding nr. 13; Utdanning for velferd (2) som vektlegger at helsearbeidere må ha forståelse og innsikt i samhandling mellom velferdstjenestene. Praksismodellen har som mål at studentene får økt innsikt i samhandling og samarbeid om pasientbehandling mellom sykehus og kommune, samt kunnskap om helheten i tjenestene og innsikt i hvordan ulike instanser utfyller hverandre.

\section{Innledning}

Utdanningsinstitusjonene skal bidra til å utdanne kompetent helsepersonell til alle deler av tjenestene $(2,3)$. Spesialisthelsetjenesten (4) og kommunehelsetjenesten (5) skal sørge for å dekke høyskolers og universiteters behov for praksisplasser. Samhandling vektlegges som ett av helse- og omsorgssektorens viktigste utviklingsområder framover (1). Dette sammen-

\section{Hovedbudskap}

Gjennom samhandlingspraksis får studenten erfaring og kunnskap om samarbeidet mellom ulike forvaltningsnivå i helsetjenesten. Dette er et viktig område som vanligvis ikke innbefattes i sykepleiestudenters praksisutdanning. Samhandlingspraksis gir antakelig nyutdannete sykepleiere bedre forutsetning for forståelse for helsetjenesten som helhet og for samarbeid om pasientbehandling på tvers av institusjons- og forvaltningsgrenser.

\section{Nøkkelord}

Les mer og finn litteraturhenvisninger på våre nettsider. > Sykepleierstudent , Sykepleierutdanning ) Samhandling faller med sykepleierutdanningens overordnete mål om å utdanne reflekterte yrkesutøvere som setter mennesket i sentrum og som kan planlegge og gjennomføre tiltak i samarbeid med brukere og andre tjenesteytere (6). Nyutdannete sykepleiere skal blant annet kjenne forvaltningsnivåene og beslutningsstrukturer i helse- og sosialsektoren, bakgrunn for helseog sosialfaglige prioriteringer og konsekvenser av slike prioriteringer, samt rammene for egen faggruppe og oppgavefordeling mellom helse- og sosialfaggruppene $(6,7)$. Sykepleiere har ansvar for å lede og organisere sykepleietjenesten på ulike nivåer innenfor egen virksomhet og på tvers av ulike helsetjenestetilbud. Forståelse og kunnskap for helsetjenestens oppbygning og fordeling av oppgaver er en av forutsetningene for faglig forsvarlig utøvelse. Denne kunnskapen tilføres gjennom teoretisk kunnskap, deltakelse i et praksisfellesskap og i samarbeid med pasienter. Læring er et grunnleggende sosialt fenomen (8). Vi lærer gjennom å handle sammen med andre mennesker i et handlingsfellesskap. Interaksjon er avgjørende for hva som blir lært. Gjennom å diskutere og reflektere med erfarne yrkesutøvere gjør studenter kunnskapen til sin egen. Aktiv læring skjer gjennom problemløsning, rettledning, oppmuntring og tilbakemelding. For studenten handler læring om å bruke informasjon og erfaringer til å forstå sammenhenger og mestre ferdigheter innenfor den virksomheten studenten befinner seg $(7,8)$.

\section{Tenke nytt}

På bakgrunn av denne forståelsen ble vi inspirert til å tenke nytt rundt praksistilbud til sykepleiestudenter. Det var også et behov for å skape nye praksisplasser, samt skape forutsigbarhet for helsetjenestene når det gjaldt antall studenter i fordypningspraksis. Over en toårsperiode ble det utviklet og etablert 16 praksisplasser per studieår, fordelt på fire perioder. Da vi ikke har funnet lignende praksismodell noe annet sted, er modellen utviklet på bakgrunn av våre felles erfaringer innenfor feltet.

\section{Praksismodellen}

Fire sykepleierstudenter i tredje året får en sju ukers praksis vekselvis i kommune- og spesialisthelsetjenesten. Studentene blir fordelt parvis mellom pasientforløp enten innen rehabilitering eller kreftbehandling og palliativ omsorg. Første og siste uke er studentene på tildelingskontoret $\mathrm{i}$ kommunen. To uker er studentene på sengepost i spesialisthelsetjenesten med hospitering på relevante dagenheter og i akuttmottak. Deretter er de tre uker i hjemmesykepleie, institusjon og ambulerende team i kommunehelsetjenesten. Studentene deltar i arbeidet på praksisstedet, men har fokus på pasienters forflytning mellom enheter internt og mellom institusjonene, innog utskrivelse av pasienter, nettverksmøter og så videre. Ved å delta på dette både når de er på tildelingskontoret, hjemmebaserte tjenester og i sykehuset, får studentene innblikk i de ulike institusjonenes fokusering i samhandlingen. På tildelingskontoret får studentene innblikk i hvordan vedtak fattes og tjenester tildeles.

\section{Mål}

Studentenes læringsutbytte for praksisen er nedfelt i åtte kunnskapsmål, ni ferdighetsmål og sju holdningsmål. Disse er oppsummert i tre overordnete mål:

, Kunnskapsmål: Studenten har kunnskap om og kan beskrive tiltak og aktiviteter som fremmer samhandlingen mellom nivåene i helsevesenet > Ferdighetsmål: Studenten anvender kunnskap om fag, lover og rammebetingelser i et samhandlingsperspektiv

, Holdningsmål: Studenten er oppmerksom på pasient/brukers samt pårørendes reaksjoner og reflekterer over samhandling i og mellom kommunehelsetjenesten og spesialisthelsetjenesten Hovedveileder og koordinator er samme person og jobber på tildelingskontoret. Vedkommende møter studentene første og siste uke, er kontaktperson underveis og deltar i sluttevalueringen. Koordinator utarbeider en detaljert plan for begge praksisforløpene, er kontaktperson for 


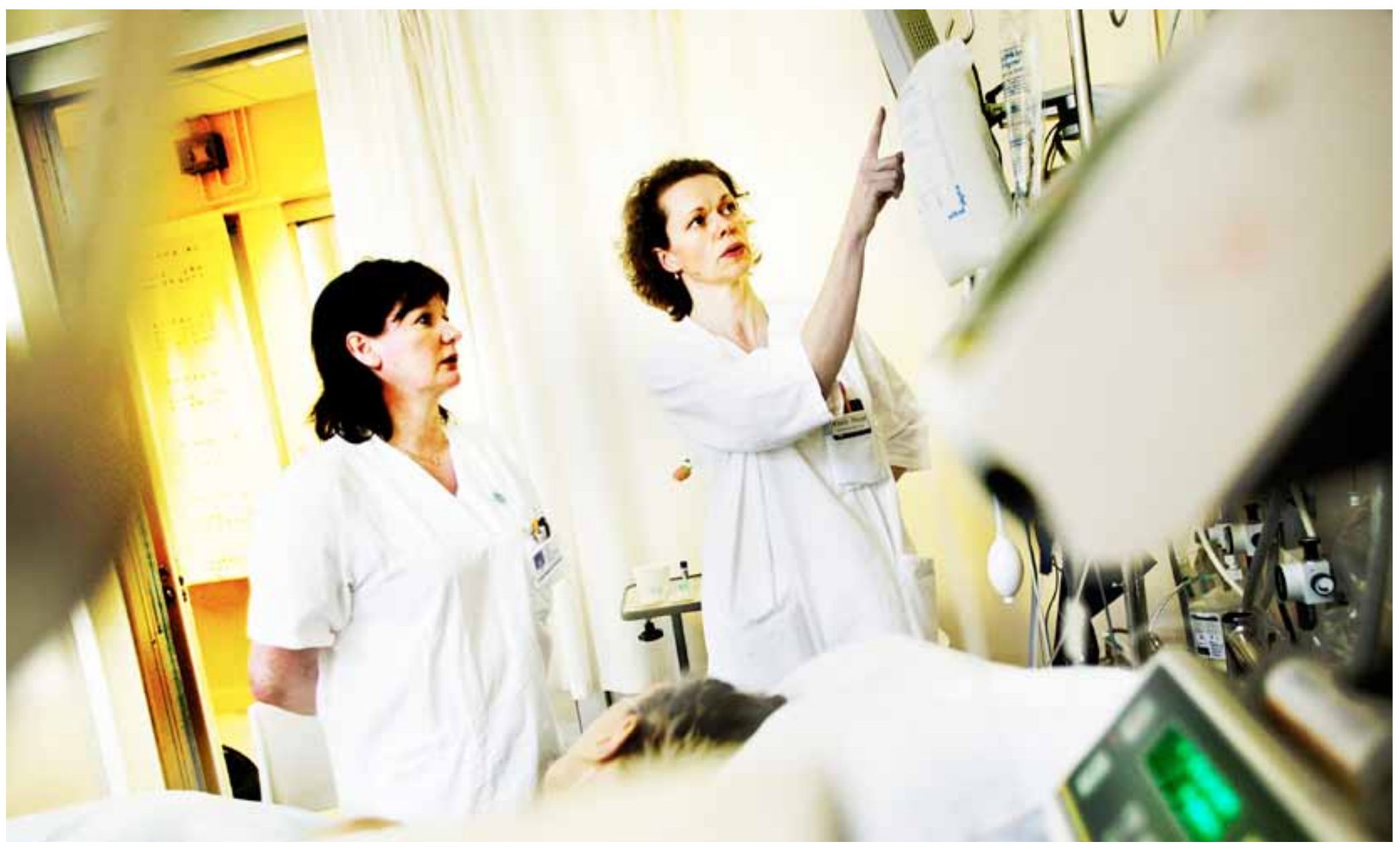

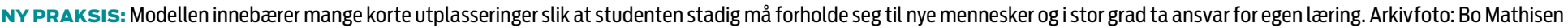

skolen og alle avdelingene. Studentene har i tillegg en daglig veileder ved hvert praksissted. Lærer møter studentene før de går i praksis, har praksisgruppe med studentene, deltar på heltidsvurderingen og mottar og gir respons på studentens ukentlige individuelle logger og refleksjonsnotater over loggene.

\section{Læringserfaringer}

I prosjektperioden samles erfaringer med praksismodellen inn gjennom samtaler med studentene, samlinger med involverte ledere i helsetjenesten og lærere i høyskolen. Studentenes erfaringer kan oppsummeres gjennom et utsagn fra en av studentene: «Jeg har fått en mye bedre oversikt over det systemet vi som sykepleiere er en del av.» Studentens uttalelse bekreftes av ledere som har rekruttert nyutdannete som har hatt samhandlingspraksis. De erfarer at disse har med seg et overblikk over helsevesenet fra denne praksisperioden som andre nyutdannete ikke har.

\section{Samarbeid}

Praksismodellen utfordrer studenten i å yte sykepleie og samtidig fokusere på samhandling. Vektlegging av systemnivå kan oppleves nytt for studenten. Tidligere praksis har ofte vært rettet mot oppfølging av den enkelte pasient og deres pårørende. Det er også større oppmerksomhet på brukerstyring i denne praksismodellen. En student oppsummerer det slik: Jeg har sett hvor viktig det er at vi samarbeider. Vi jobber med mennesker, og for et menneske er det ikke uvesentlig hvor lenge man må vente for å få plass på et rehabiliteringsopphold etter et benbrudd. Det er heller ikke uvesentlig for et menneske å vite at ens demente ektefelle ikke er alene mens man selv er på sykehus med lungebetennelse.» En annen student sier: «Mye gjenstår i forhold til gode kom- munikasjonssystemer mellom sykehus og kommune, men jeg tror det aller viktigste er at folkene som jobber med dette gjør en grundig jobb på sitt område slik at det er lett for neste ledd å gjøre sin

\section{«Jeg har fått en mye bedre oversikt over det systemet vi som sykepleiere er en del av.»}

jobb. Det krever at hver enkelt blir bevisstgjort nettopp dette, og det har vi blitt gjennom disse sju ukene!» Studentenes utsagn underbygger at de gjennom samhandlingspraksis blir bevisste på viktigheten av å gjøre en god jobb der de er, også for pasientens videre behandling. Dette er en av grunntankene i ideen om behandlingslinjer ( 9 , 10). Å se sin egen innsats som et ledd i en kjede, kan bidra til bedre flyt i pasientbehandlingen. 


\section{Korte utplasseringer}

I samhandlingspraksis må studenten hele tiden forholde seg til nye mennesker. Ofte møter de ansatte de må forklare hvem de er, hva slags praksis de er i og hvilke mål de har. Dette er ikke helt ulikt hva pasienter kan erfare, at de stadig må gjenta informasjon til nye mennesker (11). Praksismodellen forutsetter at studentene i stor grad tar ansvar for egen læring. Det forventes at studenten er delaktig, engasjert og aktiv hver dag gjennom hele perioden. Perspektivet i praksisen er uvant, og studentene må ofte ha veiledning fra veiledere og lærere både i forkant, underveis og i etterkant, til å se læresituasjoner og forstå hva de har deltatt i.

Lederne i sykehuset påpeker en utilsiktet læring ved at studentene blir vant med korte utplasseringer. Dette kan giøre det lettere som framtidig sykepleier å arbeide ved en annen enhet enn den de er til daglig. Det blir mer og mer vanlig å ha en turnus hvor sykepleiere arbeider på forskjellige enheter, for eksempel ved at sykepleiere på sengepost har vakter på poliklinikk, og omvendt.

\section{«l samhandlingspraksis må studenten hele tiden forhol- de seg til nye mennesker.»l}

I sum er studentenes erfaringer positive etter gjennomført samhandlingspraksis i møte med mange ulike aktører i helsetjenesten. Dette underbygges i litteraturen om at læring skjer gjennom å handle sammen med andre mennesker $\mathrm{i}$ et handlingsfellesskap (8).

Prosjektet har vært en av flere faktorer som har bidratt til å sette samhandling på dagsorden i høyskolen, både i teori og praksisundervisningen, og har bidratt til en endring av høyskolens rutiner ved fordeling av fordypningspraksis.

\section{Organisering}

Prosjektgruppa har bestått av representanter fra sykehus, kommune og høyskole. Det er gjennomført to til tre møter per kvartal, i tillegg til kontakt per e-post og telefon. Mange ledere og ansatte har bidratt i prosjektperioden, både i konkret oppfølging av enkeltstudenter og i utvikling av praksisløpet.

Prosjektet er finansiert via samhandlingsmidler fra Høyskolen Diakonova og arbeidsinnsats fra deltakerne. Første søknad ble sendt i mars 2009. Midlene har i hovedsak gått til å lønne en koordinator ved tildelingskontoret i 20 prosent stilling i de periodene studentene har vært ute i praksis. Våren 2011 sendte prosjektgruppen en ny søknad for et delprosjekt, hvor hovedvekten var på å utforme læresituasjoner.

Første praksisperiode ble gjennomført høsten 2010. Vi erfarte at det å innarbeide en ny praksisform krevde tid. Gjennom arbeidet med å beskrive læresituasjoner ble det blant annet tydeligere at studentene skulle følge pasientgruppers behandlingslinjer. Dette gjorde det lettere å organisere praksisperiodene og tydeliggjorde læringsmålene for studentene. Prosjektets siste og åttende praksisperiode gjennomføres oktober 2012. Fra januar 2013 er samhandlingspraksis et ordinært tilbud til studentene ved Høyskolen Diakonova.

\section{Erfaringer}

Det har vært en utfordring at studentene skal innom mange steder. Sju ledere i kommunehelsetjenesten og fire i sykehuset tar imot studentene. Det har vært arbeidet mye med å informere ledere og ansatte, slik at studentene opplever at ansatte vet hvorfor de dukker opp. Felles samlinger og workshops for ledere og veiledere er benyttet for å informere, forankre og involvere dem i utviklingen av samhandlingspraksis. Avklaring av forventninger og god informasjon i forkant til både studenter, ledere og ansatte, er med på å skape trygghet for studenten og bevisstgjøring i avdelingen. For å skape forutsigbarhet for studenter og ansatte har lederne på sykehus valgt å lage en turnus som studentene skal følge. Gjennom prosjektperioden har vi erfart at studentene har blitt bedre forberedt på hva de skal møte.

\section{Vurderinger}

Siden studentene er kort tid på hvert praksissted, har det tidvis vært en utfordring å veilede og vurdere dem. På initiativ fra ledere og veiledere $\mathrm{i}$ sykehuset er det derfor utarbeidet et vurderingsog oppmøteskjema. Skjemaet har en tallskala fra 0-4 hvor 0 står for at prestasjonen er: «mye dårligere enn forventet» og 4: «mye bedre enn forventet» på hvert av de overordnete læringsutbyttemålene. Det er også et felt for fritekst. Studenten gjør en egenvurdering, i tillegg gir den daglige veilederen en vurdering. Skjemaet skal signeres daglig av veileder, for å dokumentere oppmøte. Skjemaet benyttes i forventningssamtale i uke 1 med studentene og hovedveileder, ved de daglige vurderingene og i midtvurderingen i uke 3 med student og veileder på sykehuset. Lærer og student benytter skjema i praksisgruppe i uke 4 og i refleksjonsnotater og tilbakemeldinger.

\section{Konklusjon}

I en oppstartsfase anbefaler vi tett kontakt mellom helsetjenestene og høyskolen. Studenten bør gjennom selvstudium og undervisning fra høyskolen gjøre seg kjent med de ulike nivåene i helsevesenet før de starter i samhandlingspraksis. Overordnet ukeplan, beskrevet læringsutbytte og fastlagt koordinering og veiledning fra høyskole, kommune- og spesialisthelsetjenesten kan overføres til andre distrikter i Norge og dels til andre helsefagutdanninger. Imidlertid må læringsutbytte tilpasses den enkelte helsefaglige utdanning. Man kan forsøke å prøve ut praksismodellen sammen med andre helsefaggrupper. Man antar at studentene vil få en bredere kunnskap om hverandres profesjon, noe som på sikt vil gi en nytteeffekt $i$ helsetjenesten generelt.

Samhandlingspraksis er utviklet for å møte den nye og forsterkete politiske og faglige anbefalingen om samhandling mellom forvaltningsnivåene. Utdanning av framtidens sykepleiere bør til enhver tid avspeile samfunnets behov for sykepleie. Vi antar at sykepleiere som har deltatt i samhandlingspraksis gjennom sin utdanning, har bedre forutsetninger til å ha innsikt i samhandling og samarbeid om pasientbehandling på ulike nivåer i helsetjenesten. En systematisk evaluering av denne praksismodellen i et helhetlig perspektiv er derfor ønskelig.

Vi takker studentene som har deltatt, involverte ledere, sykepleiere og andre helsearbeidere og kolleger som har gjort det mulig å gjennomføre prosjektet. IIII

\section{REFERANSER \\ St.meld.nr. 47 (2008-2009). Samhandlingsreformen: rett behandling - på rett sted - til rett tid Oslo: Helse- og omsorgsdepartementet. \\ Meld. St. 13 (2011-2012). Utdanning for velferd. Samspill i praksis Oslo: Kunnskapsdepartementet. \\ 3. Universitets- og høyskoleloven. LOV-1986-07-11-53 Lov om universiteter og høyskoler. Oslo: Kunnskapsdepartementet. \\ Spesialisthelsetjenesteloven. LOV-1999-07-02-61 Lov om spesialisthelse- tjenesten m.m. Oslo: Helse- og omsorgsdepartementet. \\ Helse- og omsorgstjenesteloven. LOV-2011-06-24-30 Lov om kommunale helse- og omsorgstjenester m.m. Oslo: Helse- og omsorgsdepartementet. \\ Kunnskapsdepartementet Rammeplan for sykepleierutdanning: fastsatt 25. januar 2008 Oslo: Kunnskapsdepartementet. \\ 7. Høgskolen Diakonova. Fagplan for sykepleierutdanning, Bachelor i sykepleie. www.diakonova.no 2007 . \\ 8. Dysthe O. (2001) red. Dialog, samspel og læring. Oslo: Abstrakt forlag. \\ 9. Rotter T, Kinsman L, James E, Machotta A, Gothe H, Willis J, et al. Clinical pathways: effects on professional practice, patient outcomes, length of stay and hospital costs. Cochrane Database of Systematic Reviews. 2010:1-123. \\ 10. Reiner LM. Behandlingslinjer reduserer komplikasjoner for pasienter i syke- hus. Sykepleien Forskning. 2010;5: 92-3. \\ 11. Skudal KE, Holmboe O. Pasienters erfaringer med norske sykehus i 2011. Resultater for regioner og foretak. PasOpp rapport nr. 4-2012 Oslo: Nasjonalt kunnskapssenter for helsetjenesten, 2012.}

Fagartikler kan sendes til torhild.apall@sykepleien.no 